University of California, Hastings College of the Law UC Hastings Scholarship Repository

Faculty Scholarship

2011

\title{
Mancession or "Momcession"?: Good Providers, a Bad Economy, and Gender Discrimination
}

Joan C. Williams

UC Hastings College of the Law, williams@uchastings.edu

Allison Tait

Follow this and additional works at: http://repository.uchastings.edu/faculty_scholarship

Part of the Civil Rights and Discrimination Commons, and the Law and Gender Commons

\section{Recommended Citation}

Joan C. Williams and Allison Tait, Mancession or "Momcession"?: Good Providers, a Bad Economy, and Gender Discrimination, 86 Chi.Kent. L. Rev. 857 (2011).

Available at: http://repository.uchastings.edu/faculty_scholarship/835

This Article is brought to you for free and open access by UC Hastings Scholarship Repository. It has been accepted for inclusion in Faculty Scholarship by an authorized administrator of UC Hastings Scholarship Repository. For more information, please contact marcusc@uchastings.edu. 


\title{
UNIVERSITY of CALIFORNIA HASTINGS COLLEGE OF THE LAW
}

\section{Faculty Publications}

UC Hastings College of the Law Library

\author{
Author: Joan C. Williams \\ Source: $\quad$ Chicago-Kent Law Review \\ Citation: $\quad 86$ CHI.-Kent L. ReV. 857 (2011). \\ Title: $\quad$ "Mancession" or "Momcession"?: Good Providers, a Bad Economy, and Gender \\ Discrimination
}

Originally published in CHICAGO-KENT LAW REVIEW. This article is reprinted with permission from ChicAgo-Kent LaW ReVIeW and Chicago-Kent College of Law. 


\title{
"MANCESSION" OR "MOMCESSION"?: GOOD PROVIDERS, A BAD ECONOMY, AND GENDER DISCRIMINATION
}

\author{
JOAN C. WILLIAMS* AND ALLISON TAIT**
}

\section{INTRODUCTION}

When the financial crisis hit in 2008 and the markets plummeted to a staggering low, a commonplace trope for news commentators was to talk about the bad economy as the worst since the Great Depression. ${ }^{1}$ This comparison was a shorthand way to signal both the economic severity and the sociological impact of the change. "This has been the worst financial crisis since the Great Depression. There is no question about it," Mark Gertler, a New York University economist and former colleague of Ben Bernanke, was quoted as saying in a Wall Street Journal article. ${ }^{2}$ As a U.S. News \& World Report article stated, "Plenty of observers are willing to say that this recession is much deeper than anything we've seen since the 1930 s-including the big dip in the early 1980s, generally accepted as the other candidate for the worst recession since the Great Depression."3 Analysts and pundits of all political stripes used this analogy repeatedly, and soon it was a stock campaign phrase as well. 4

In practical terms, what was happening in workplaces and neighborhoods seemed to confirm conventional wisdom about the historic nature of the economic downturn. Foreclosures skyrocketed, ${ }^{5}$ job loss continued

* Joan C. Williams is Distinguished Professor of Law and Founding Director of the Center for WorkLife Law at University of California, Hastings College of the Law.

** Allison Tait is a J.D. candidate 2011 at Yale Law School.

1. Jon Hilsenrath, Serena Ng \& Damian Paletta, Worst Crisis Since '30s, with No End Yet in Sight, WALl ST. J. (Sept. 18, 2008), http://online.wsj.com/article/SB122169431617549947.html; Bob Willis, U.S. Recession Worst Since Great Depression, Revised Data Show, BLOOMBERG (Aug. 1, 2009), $\mathrm{http}: / / \mathrm{www}$.bloomberg.com/apps/news?pid=newsarchive\&sid=aNivTjr852TI.

2. Hilsenrath, supra note 1.

3. Matthew Bandyk, Is Unemployment the Worst Since the Great Depression?, U.S. NEWS \& WORLD REPORT (Aug. 27, 2009), http://money.usnews.com/money/businesseconomy/articles/2009/08/27/is-unemployment-the-worst-since-the-great-depression.

4. World Bank: Economy Worst Since Depression, CNNMONEY.COM (Mar. 9, 2009), http://money.cnn.com/2009/03/09/news/international/global_economy_world_bank/.

5. Les Christie, Foreclosures Climb in 75\% of Metro Areas, CNNMONEY.COM (July 29, 2010), http://money.cnn.com/2010/07/29/real_estate/new_face_of_foreclosure/index.htm. 
unabated month after month, ${ }^{6}$ and the bad economy took a toll on households across the nation as families lost their homes and men and women lost their jobs. In October 2010, the unemployment rate hit a high of $10.1 \%$, a rate not seen since the early $1980 \mathrm{~s}^{7}$ The Bureau of Labor Statistics reported that the average duration of unemployment had passed the sixmonth mark, a high never previously recorded by the Bureau of Labor Statistics since it began keeping records in $1948 . .^{8}$ In March 2010, informed by these high and persistent rates of joblessness, an article in The Atlantic stated that:

The broadest measure of unemployment and underemployment . . . reached 17.4 percent in October, which appears to be the highest figure since the 1930s. And for large swaths of society-young adults, men, minorities - that figure was much higher (among teenagers, for instance, even the narrowest measure of unemployment stood at roughly 27 percent). One recent survey showed that 44 percent of families had experienced a job loss, a reduction in hours, or a pay cut in the past year. ${ }^{9}$

What the numbers could not capture were the anxiety and insecurity that surrounded employment status as well as the new importance of both finding and keeping work. Despite the somewhat ironic fact that the recession was declared to be technically over in June 2009, journalists recorded no similar end to the anxieties besetting the population. ${ }^{10}$ Observers noted, "On the day that the Great Recession was officially declared to be part of history, President Obama confronted deepening angst from business leaders and ordinary Americans who have little faith that the recovery is for real."ll In a Washington Post article, a forty-nine year old bicycle messenger was quoted as saying, "Maybe the economy got better for rich folks with good jobs . . . but for the blue-collar worker it hasn't gotten better. No,

6. Don Peck, How a New Jobless Era Will Transform America, ThE ATLANTIC (Mar. 2010), http://www.theatlantic.com/magazine/archive/2010/03/how-a-new-jobless-era-will-transform-america/ $7919 /$.

7. Sizing up the 2007-09 Recession: Comparing Two Key Labor Market Indicators with Earlier Downturns, U.S. BUREAU OF LABOR STATISTICS, 2 (Dec. 2010), www.bls.gov/opub/ils/pdf/opbils88.pdf.

8. Mortimer Zuckerman, The Economy Is Even Worse Than You Think, WaLL ST. J. (July 14, 2009), http://online.wsj.com/article/SB124753066246235811.html ("The average length of official unemployment increased to 24.5 weeks, the longest since government began tracking this data in 1948 . The number of long-term unemployed (i.e., for 27 weeks or more) has now jumped to 4.4 million, an all-time high.").

9. Peck, supra note 6.

10. Neil lrwin \& Nia-Malika Henderson, Recession is Officially Over, but Anxiety Lingers, WASH. POST (Sept. 21, 2010), http://www.washingtonpost.com/wp-dyn/content/article/2010/09/20/ AR2010092006355.html.

11. Id. 
no way." 12 Even those in the professional class had their doubts. This much was clear when a law school graduate confronted President Obama at a forum on jobs and the economy with this question: "Is the American dream dead for me?"13

Against this backdrop of precarious and disappearing work, two new elements became important: who was out of work, and how those still employed were navigating bad jobs. These questions laid the foundation for a flood of stories concerning unemployment and bad employment. Unsurprisingly, gender played a leading role in the debates. ${ }^{14}$ This article will discuss these two concerns-employment and workplace discrimination-as they intersect with gender and gender stereotypes. The article will begin by looking at how employment numbers during the recent economic downturn first took on a gendered description when it was discovered that men were in industries hardest hit by the downturn. ${ }^{15}$ This discussion will explore how the resulting "mancession" not only troubled the ideal of the male as good provider, instigating many conversations about masculinity and its evolving definition, ${ }^{16}$ but also correlated with new legal claims that men made when they were discriminated against in the workplace for taking on care-giving roles at home. ${ }^{17}$ The article will subsequently discuss the effects of this "mancession" on women and how the rhetoric of the "mancession" elided continuing gender discrimination against women-women who were often placed in the position of being the sole family provider by the recession, single women with family responsibilities, and, more generally, women as they comprise the majority of caretakers. ${ }^{18}$ The bad economy brought into sharp focus the flaws and the fallacies of the "good provider" stereotype while simultaneously continuing to create hurdles for reconciling the provider stereotype with the prescriptively normative model of caretaking.

12. Id.

13. Joan C. Williams, Obama and the Democrats Must Reconnect with Working-Class Voters, WASH. POST (Sept. 26, 2010), http://www.washingtonpost.com/wp-dyn/content/article/2010/09/24/ AR2010092402437.html.

14. See infra Part I.

15. For the proposition that men were hardest hit by the recession, see sources cited infra notes 21-30 and accompanying text.

16. See infra Part $\mathrm{I}$.

17. See infra Part II.

18. See infra Part III. 


\section{I. "MANCESSION": MALE UNEMPLOYMENT AND THE (FAILED) GOOD PROVIDER}

In January 2009 , in the midst of bad news coming from all sides about the economy and joblessness, Casey B. Mulligan, an economist from the University of Chicago, pointed out in a blog post for the New York Times that women would soon account for fifty percent of employment. ${ }^{19} \mathrm{~A}$ month later, another article proclaimed, "Women are poised to surpass men on the nation's payrolls, taking the majority for the first time in American history." 20 Most of these articles and posts, however, noted that women's gains came at a cost. ${ }^{21}$ The fifty percent milestone "would of course be a bittersweet milestone, given that it comes primarily as a result of men's layoffs." 22 As one article admitted, "The reason [for women's success] has less to do with gender equality than with where the ax is falling." 23 Commentators encountered little difficulty finding an explanation, declaring that "[w]omen tend to be employed in areas like education and health care, which are less sensitive to economic ups and downs, and in jobs that allow more time for child care and other domestic work." 24 Men, on the other hand, were more likely to be employed in areas that were hard-hit by the bad economy, like manufacturing and construction. ${ }^{25}$ Because of the different representation of men and women in particular industries, Heather Boushey, an economist for the Center for American Progress, testified before the Equal Employment Opportunity Commission (EEOC) in April 2009 that, "[w]hile men and women had similar unemployment rates at the beginning of the recession, men now have much higher unemployment rates and the percentage point gap between men's and women's unemployment is at its highest ever." 26 Once the reason for women's gains was identified as linked with a large decrease in men's employment, the story quickly changed. 27 The story became about the "mancession" and the fact that "a

19. Casey B. Mulligan, Blog Post, A Milestone for Working Women?, NEW YORK TIMES (Jan. 14, 2009), http://economix.blogs.nytimes.com/2009/01/14/a-milestone-for-women-workers/.

20. Catherine Rampell, As Layoffs Surge, Women May Pass Men in Job Force, NEW.YORK TIMES (Feb. 5, 2009), http://www.nytimes.com/2009/02/06/business/06women.html?.

21. Catherine Rampell, Blog Post, The Mancession, New YORK TIMES (Aug. 10, 2009), http://economix.blogs.nytimes.com/2009/08/10/the-mancession/.

22. Id.

23. Rampell, supra note 20 .

24. Id.

25. Rampell, supra note 21 .

26. Heather Boushey, Will Economic Trends Change Family Dynamics?, CENTER FOR AMERICAN PROGRESS ACTION FUND (Apr. 22, 2009), http://www.americanprogressaction.org/issues/2009/04/ eeoc_testimony.html.

27. Id. 
full 82 percent of the job losses have befallen men." 28 With dramatic flourish, one economics professor wrote, "There has probably never been a previous recession in U.S. history where the negative effects of unemployment and job losses fell so disproportionately on one gender."29 The title of a blog post put it more succinctly: "It's Not Just a Recession. It's a Mancession!"30

Once the statistics gave way to the phenomenon, the idea of mancession began to yield not only economic but also psychological outcomes for men. A Newsweek article about the mancession said this:

The term "mancession" began quaintly enough. ... [M] edia outlets from Foreign Policy to The New York Times [have taken] the term one step further, calling it the death of the macho, or the he-cession. If you Google mancession now, it'll turn up 13,500 hits. ${ }^{31}$

Even the blog Gawker got in the action and had something to say about the mancession, calling it "Our Favorite New Word." 32 The blog described "mancession" as being "kind of like a manwich, but instead of robust, smoky beef flavor, it's chock full of depression, unemployment, an unshakable feeling of shame, and sisterhood." 33 Mancession was not just about some bad numbers and an unintended rise in employment for women. The mancession was about the troubled male psyche and the toll that unemployment and underemployment were taking on it. One article in The Atlantic cited Mirra Komarovsky's classic Depression-era study of unemployed men, The Unemployed Man and His Family, ${ }^{34}$ to explain the particular difficulty that men experienced when faced with unemployment:

Especially in middle-aged men, long accustomed to the routine of the office or factory, unemployment seems to produce a crippling disorientation. At a series of workshops for the unemployed... around Philadelphia last fall, the participants were overwhelmingly male, and

28. Rampell, supra note 20.

29. Mark J. Perry, The Great Mancession of 2008-2009, AMERICAN INSTITUTE FOR PUBLIC POLICY RESEARCH, 1 (June 17, 2010), http://www, aei.org/docLib/GreatMancessionTestimony.pdf.

30. Derek Thompson, It's Not Just a Recession. It's a Mancession!, THE ATLANTIC (July 9, 2009), http://www.theatlantic.com/business/archive/2009/07/its-not-just-a-recession-its-a-mancession/20991/.

31. Nancy Cook, What Mancession?, NewsweEK (July 16, 2009), http://www.newsweek.com/2009/07/15/what-mancession.html.

32. John Cook, Our Favorite New Word: Mancession, GAWKER (Aug. 10, 2009, 5:32 PM), http://gawker.com/\#!5334275/our-favorite-new-word-mancession.

33. Id.

34. Peck, supra note 6 (citing MIRRA KoMAROVSKY, THE UNEMPLOYED MAN AND HIS FAMILY (AltaMira Press 2004) (1940)). 
the men in particular described the erosion of their identities, the isolation of being jobless, and the indignities of downward mobility. ${ }^{35}$

Male joblessness, the article suggested, not only led to diminished male confidence, but also produced a host of relationship problems, including increased domestic violence, by creating a shift in family and marital dynamics and expectations. ${ }^{36}$ In February 2010, Senate Majority Leader Harry Reid mentioned this link in talking about the jobs bill, saying, "Men, when they're out of work, tend to become abusive." 37 Reid continued by noting, "Women don't have jobs either, but women aren't abusive, most of the time." 38 Put in different terms, Kathryn Edin's research affirmed the same central concept-that "men's identities are far more defined by their work than women's, and both men and women become extremely uncomfortable when men's work goes away."39

What became apparent, through the lens of the mancession, was that while certain industries were a casualty of declining fortunes, the larger victim was a particular vision of male identity, related to the idealized notion of the good provider. The recession had as its unintended target critical psychological components of manhood and, equally important, deeply ingrained ideas about male dominance in the job market. The mancession served to uncover and underscore stereotypes creating traction around gender roles and the notion of providing for a family. The outcome of the mancession was that male and female stereotypes had equal purchase, and that these stereotypes served the purpose of policing gender roles equally well. The mancession emphasized that men were supposed to be gainfully employed-and were consequently adrift and awash in feelings of inadequacy when they were not. The mancession showed, ultimately, that men were shaped through their employment rather than by other experiences or affiliations.

35. Id.

36. Id. ("Last March, the National Domestic Violence Hotline received almost half again as many calls as it had one year earlier; as was the case in the Depression, unemployed men are vastly more likely to beat their wives or children.").

37. Michael O'Brien, Reid: 'Men, When They're Out of Work, Tend to Become Abusive', THEHILL.COM (Feb. 22, 2010), http://thehill.com/blogs/blog-briefing-room/news/82803-reid-menwhen-theyre-out-of-work-tend-to-become-abusive.

38. Id.

39. Peck, supra note 6. ("Many working women struggle with the idea of partners who aren't breadwinners. 'We've got this image of Archie Bunker sitting at home, grumbling and acting out,' says Kathryn Edin, a professor of public policy at Harvard, and an expert on family life. 'And that does happen. But you also have women in whole communities thinking, 'This guy's nothing."'). 


\section{Male Discrimination Claims: The Risks of Gender Deviance FOR MEN}

As the mancession took jobs from men and stripped them of important sources of self-worth and self-definition, men came to be portrayed in nonmasculine ways. Following the logic that men in the middle of a mancession were men in crisis, the economic downturn generated stories not only of male dispossession but also of male powerlessness. These sentiments were visible in stories about increases in male claims of workplace harassment. ${ }^{40}$ Men were now victims--and not just of a bad job market. Men were suddenly equally vulnerable to powerful bosses, bad working conditions, and a host of other demeaning conditions. The mancession discourse inverted gender roles and, while women became privileged earners and competitive labor-market players, men became ineffective, unemployed, and feminized targets of workplace hostility and discrimination.

One headline encapsulated this new vulnerability, stating that "[m]ale sexual harassment is sure having a moment." 41 Another article provided statistics that confirmed the spike in filings:

Since the start of the recession, a growing number of sexual harassment complaints have come from men. Some $16.4 \%$ of all sexual harassment claims - or 2,094 claims-were filed by men in fiscal 2009, up from $15.4 \%$, or 1,869 claims, in fiscal 2006.42

The article noted that it was not unusual to see a spike in employment litigation during a recession. ${ }^{43}$ Remarkably, however, this time the increase in claims came from men, and from many more men than expected. ${ }^{44}$ Another article cautioned that "[i]t's hard to say whether sexual harassment against men has actually increased or whether more men are simply going public with it." 45 One theory that commentators put forward was that, given the economic climate, men no longer saw quitting as a plausible option for ending a bad workplace situation and were therefore more willing to come forward with claims. ${ }^{46}$ Heather Boushey testified in front of the EEOC that

40. Tracy Clark-Flory, Male Sexual Harassment and the "Mancession," SALON.COM (Mar. 23, 2010), http://www.salon.com/life/broadsheet/2010/03/23/male_sexual_harassment.

41. Id.

42. Dana Mattioli, More Men Make Harassment Claims, WALL ST. J. (Mar. 23, 2010), http://online.wsj.com/article/SB10001424052748704117304575137881438719028.html.

43. Id.

44. Id.

45. Clark-Flory, supra note 40 .

46. Id. 
"[1]osing a job in this economy could mean significant hardship for families."47

Another theory built more on the psychological outcomes of male unemployment. Relating the rise in claims back to the concept of "mancession," one article concluded by positing that "the financial crisis has men feeling more open to seeing themselves as victims; and, if the popularity of the term 'mancession' is any indication, maybe both men and women are increasingly open to the idea of guys being victimized." 48 While the "mancession" robbed many men of their status as good providers, the cut went even deeper, bringing to the fore the concept that masculine identity was vulnerable and subject to victimization.

While masculine identity was left open to redefinition thanks to changed economic circumstances, the results were not always applauded. Both harassment and discrimination cases emphasized that male workers were penalized when they acted against conventional workplace roles, and men were placed in their own particular double bind-unable to be good providers and yet disallowed from taking up new roles as caregivers. Social psychologists like Laurie Rudman have found that there is a significant backlash against men who do not conform to gender stereotypes and that, while '[t]erms like 'sensitive new age man' and 'metrosexual' reflect changes in gender roles that ought to afford men more latitude for communality and less demand for agency," research in fact predicts that men are and will continue to be held to "a high standard of agency (and a low standard of communality)." 49 Thus, while men-especially unemployed or underemployed men -were recast as victims of a bad economy and, consequently, as powerless in the workplace, they risked experiencing heightened discrimination in and out of the workplace for deviating from gender norms. ${ }^{50}$ As Rudman and her colleagues found, "men are still required to uphold masculine ideals that require chronic exhibitions of strength while avoiding signs of weakness," and "atypical men are at risk for backlash." 51

47. Boushey, supra note 26.

48. Clark-Flory, supra note 40 . The usual response, absent the "mancession," to male-on-male is less sympathetic: "As Ron Chapman, an attorney with an employment law firm, tells the Journal, most people respond to stories of guy-on-guy sexual harassment along the lines of 'Why didn't the guy just hit him upside the head?"' $I d$. Whereas the reaction to female harassment of male employees is "considered the stuff of masculine fantasy." Id.

49. Corinne A. Moss-Racusin, Julie E. Phelan \& Laurie A. Rudman, When Men Break the Gender Rules: Status Incongruity and Backlash Against Modest Men, 11 PSYCHOL. OF MEN \& MASCULINITY 140, 140 (2010); see also LAURIE A. RUDMAN \& PETER GLICK, THE SOCIAL PSYCHOLOGY OF GENDER: HOW POWER AND INTIMACY SHAPE GENDER RELATIONS 156-78 (2008).

50. Moss-Racusin et al., supra note 49 , at 147 .

51. Id. 
This phenomenon of punishing gender deviance for men as well as women is evident in cases of male family responsibilities discrimination (FRD), which, like harassment claims, appear with some regularity and draw attention to the penalties and punishment men experience when they deviate from conventional gender roles. ${ }^{52}$ Descriptively stereotyped as good providers, men who choose to take active roles in family care may be seen not only as less masculine, but also as deficient fathers, given that being a good provider is part of the "package" of being (seen as) a good father. ${ }^{53}$ Claims show that working men who openly demonstrate that they have caregiving responsibilities are viewed as being less dependable, less ambitious and driven, and often engaged in gender-inappropriate work. ${ }^{54}$ Claims also show prescriptive stereotyping: Employers often communicate that men should behave like traditional breadwinners who are always available when their employers need them. 55

Male FRD occurs primarily when male workers experience harassment or penalty for taking time off to help care for newborns, ${ }^{56}$ for aging parents, ${ }^{57}$ or for sick spouses or partners. ${ }^{58}$ Discrimination against male

52. See infra Part II.A-D; see also Joan C. Williams \& Stephanie Bornstein, The Evolution of "FReD": Family Responsibilities Discrimination and Developments in the Law of Stereotyping and Implicit Bias, 59 HASTINGS L.J. 1311, 1320-21 (2008).

53. See nicholas W. Townsend, The PaCkage Deal: Marriage, Work, and Fatherhood IN MEN's LIVES 117-37 (2005) ("Men who do not have jobs are frequently branded as unworthy, morally inferior, and failures as men.").

54. See cases cited infra Part II.A-D. This analysis is also based on a review of cases contained in the Center for WorkLife Law's database of more than 2,100 cases. See CYNTHIA ThOMAS CALVERT, CENTER FOR WORKLIFE LAW, FAMILY RESPONSIBILITIES DISCRIMINATION: LITIGATION UPDATE 2010 app. at 25 (2010) (describing the Center's methodology in developing and maintaining the database).

55. See, e.g., Complaint and Jury Demand at 5-8, Ayanna v. Dechert, No. 1:10-cv-12155-NMG, (D. Mass. Dec. 14, 2010) (alleging that male attorney was discriminated against because he took much more leave than other male attomeys and, in fact, other males "bragged about how little time they spent on family obligations").

56. See, e.g., Knussman v. Maryland, 272 F.3d 625, 625 (4th Cir. 2001) (male state trooper brought FMLA claim after supervisor told him that "God made women to have babies" and that his wife would have to be "dead or in a coma" before he could get family medical leave to care for his newborn child); Shafer v. Bd. of Pub. Educ., 903 F.2d 243, 244 (3d Cir. 1990) (male school teacher was denied one-year child-rearing leave even though such leave was available to female employees).

57. See, e.g., Scamihorn v. General Truck Drivers, 282 F.3d 1078, 1080-81 (9th Cir. 2002) (male employee rehired as probationary employee after taking leave to care for sick father); Plaintiff's Response to Defendant's Motions in Limine at 3-4, Schultz v. Advocate Health \& Hosps. Corp., No. 01cv-0702, 2002 WL 32603929 (N.D. Ill. May 31, 2002) (male maintenance worker brought FMLA and retaliation claim after being terminated while on intermittent FMLA leave to care for father who had Alzheimer's and for sick mother).

58. See, e.g., Nielsen v. New Cingular Wireless PCS, No. 05-320-JO, 2006 U.S. Dist. LEXIS, at *1-6 (D. Or. Jan. 31, 2006) (male employee terminated in retaliation for taking leave to care for pregnant wife who was experiencing medical complications); Complaint at 2, Carroll v. Tropical Aquaculture Prods., No. 02-08-cv-138 (D. Vt. July 7, 2008) (alleging that male employee had been discharged in retaliation for taking leave to care for his wife, who was undergoing in-vitro fertilization); Verdict and Settlement Summary, Wamel v. Ocelot Engineering Inc., No. CIVSS702877, 2008 WL 3166823 
caregivers takes various forms, including holding men with family responsibilities to higher standards, ${ }^{59}$ hyper-scrutinizing their work, ${ }^{60}$ interfering with their ability to take leave as guaranteed by the Family and Medical Leave Act (FMLA), ${ }^{61}$ or retaliating against men who take FMLA leave (typically via wrongful demotion or termination). ${ }^{62}$ The majority of these cases show up in federal district court as claims of interference or retaliation with FMLA leave. ${ }^{63}$ Less common are claims that rely on state versions of the Family and Medical Leave Act, or common law claims such as wrongful termination. ${ }^{64}$ Often, these claims intersect with race discrimination claims. ${ }^{65} \mathrm{~A}$ quick review of the male FRD cases (approximately fifteen to twenty percent of the Center for WorkLife Law's database) brings out four common themes, which are discussed in the next four sections. ${ }^{66}$

\section{A. Questioning Male Commitment to the Job}

Problems often begin between the male employee and his supervisor or company as soon as he requests FMLA leave. In Bailey v. Miltope

(Cal. Super. Ct. July 7, 2008) (arbitrator found that male employee was wrongfully terminated after taking leave to care for his wife who was sick with cancer).

59. See, e.g., Bell v. Prefix, Inc., 32I Fed. Appx. 423, 430-31 (6th Cir. 2009) (male employee told that "everyone" needed to work more hours and subsequently fired after he took FMLA leave to care for his dying father, even though employee had highest rating for work output on performance evaluations).

60. See, e.g., Dotson v. Pfizer, 558 F.3d 284, 291-92 (4th Cir. 2009), cert. denied 130 S. Ct. 114 (2009), cert. denied $130 \mathrm{~S}$. Ct. 201 (2009) (male sales representative for Pfizer succeeded on FMLA claim after he was terminated for violation of an allegedly arbitrary "policy" used as a pretext for firing him after he took leave to adopt child from Russia).

61. Family and Medical Leave Act of $1993 \$ 105(a)(1), 29$ U.S.C. $\$ 2615(a)(1)$ (2006) ("It shall be unlawful for any employer to interfere with, restrain, or deny the exercise of or the attempt to exercise, any right provided under this title ...."); see, e.g., Kauffman v. Fed. Express Corp., 426 F.3d 880, 88485 (7th Cir. 2005) (employer improperly granted summary judgment where male employee presented enough evidence to establish claim of interference with FMLA rights).

62. Id. \$105(a)(2), 29 U.S.C. $\$ 2615$ (a)(2) ("It shall be unlawful for any employer to discharge or in any other manner discriminate against any individual for opposing any practice made unlawful by this title ...."); see, e.g., Stallings v. Hussmann Corp. 447, F.3d 1041, 1052-53 (8th Cir. 2006) (reversing summary judgment in favor of employer where male employee claimed he was terminated in retaliation for taking FMLA leave to care for his sick father).

63. CALVERT, supra note 54 at 11 (describing the laws used in FRD cases).

64. Id.

65. See, e.g., Shark v. City of New York, No. 1:03-cv-02616-PKC, 2008 WL 4444122, at *1 (S.D.N.Y. Sept. 29, 2008) (alleging discrimination on account of race and interference with FMLA rights); Parker v. Winter, EEOC Appeal No. 0120071350, 2008 EEOPUB LEXIS 1903, at *3 (May 29, 2008) (alleging discrimination on the basis of race based, in part, on denial of sick leave to care for family member); Brown v. Dep't of the Air Force, DA-0752-08-0005-1-1, 2008 MSPB LEXIS 524, at ${ }^{*} 12,{ }^{*} 15-17$ (M.S.P.B. Jan. 29, 2008) (alleging discrimination on account of race and retaliation for violating leave policies).

66. To date, the Center for WorkLife Law has collected more than 2,100 cases in a case database. CALVERT, supra note 54, at 25. 
Corp., a male employee wanted to take time off to care for his father, who had been diagnosed with cancer and given three to six months to live, but was discouraged from doing so by the employer's Vice President of Administration, Edward Crowell.67 As the decision states, "Crowell told Plaintiff how important his job was and that the company really needed him. Crowell also told Plaintiff a story about his father, who also had cancer. Crowell said that even though his father was sick, he was able to spend a lot of time with him." 68 When the employee, Patrick Bailey, failed to call in his absences for three consecutive days, "Crowell sent him a letter dated November 12, 2003, stating that he was considered to have voluntarily resigned and that his employment with Defendant was terminated."69

In another case, Hayden $v$. Garden Ridge Management, a member of the human resources department responded to a male employee's request for FMLA leave by remarking that "[i]t's very strange that we have a male manager request that amount of time off, we have never had that before."70 Similarly, in Rabe v. Nationwide Logistics, Inc., the employer allegedly told a male senior accountant that he could not take FMLA leave when his wife gave birth if things were "really busy" at the office, stating that the employee did not have same rights as his female colleagues. ${ }^{71}$ The same type of disbelief and dissuasion appeared in the case Rasic $v$. City of Northlake, ${ }^{72}$ in which a supervisor told a male employee who was out on FMLA leave to take care of both his son and his ailing parent:

All right, I'm not letting you take off the summer anymore like this, Dan, okay. Everybody else has kids. You need to start making some plans to come back, okay ... a lot of people are dealing with elderly parents that are sick and terminally ill ... You got to come back to work though, you know. I mean, you know, you're going to be off all summer here. It's a

67. Bailey v. Miltope Corp., 513 F. Supp. 2d 1232, 1235 (M.D. Ala. 2007).

68. Id. "Plaintiff believes that Crowell said that his family helped him take care of his father. Plaintiff felt after hearing this that maybe he could take care of everything without needing FMLA leave. Plaintiff alleges that Crowell's statements constituted an attempt to discourage him from taking leave." Id. The court found that this conversation did not amount to discouragement from taking leave. Id. at 1241 . 1241 .

69. Id. at 1236 . In the end, the court granted summary judgment in part for the employer. Id. at

70. No. 4:08-cv-172-DDB, 2009 WL 5196718, at *4 (E.D. Tex. Dec. 22, 2009). The employee was eventually terminated, but the gender discrimination claim failed because he was replaced by a male. $I d * 5$.

71. Rabe v. Nationwide Logistics, Inc., 530 F. Supp. 2d 1069, 1073 (E.D. Mo. 2008).

72. Complaint at 1, Rasic v. City of Northlake, No. 1:08-C-104 (N.D. Ill. Jan 7, 2008), 2008 U.S. Dist. Ct. Pleadings LEXIS 706. 
busy summer. We got a lot of people filling in for you and stuff. You got to start thinking of the department too, you know, okay? ${ }^{73}$

In a case about in vitro-fertilization (IVF), Michael Carroll, a male employee who was working as a Vice-President of Sales, notified his boss that his wife would be undergoing IVF and that he would need several days off to care for her as well as to participate in the process. ${ }^{74}$ The day before this was to happen, Carroll and his boss had a conversation which, according to the plaintiff's complaint, consisted of Carroll's supervisor suspending Carroll and telling him "that he was angry he had requested time off for his wife's surgery and not to return until the following week."75

Finally, a recent claim filed by a law firm associate exemplifies the ways in which an employer can either create or allow a culture that penalizes caretakers to thrive. ${ }^{76}$ In Ayanna v. Dechert, a law firm associate with a mentally ill wife and two young children claimed that the culture at the firm was a "macho" one that "praise[d] and encourage[d] male associates and partners to fulfill the stereotypical male role of ceding family responsibilities to women."'77 When Ayanna's second child was born and his wife's condition was deteriorating, he took the full paid paternity leave offered by the firm and intended to take the full amount of FMLA leave allowed by law. 78 Ayanna returned early, however, because of the firm's "hostility" toward his taking FMLA leave. ${ }^{79}$ Once he returned from FMLA leave, the hostility increased.80 Ayanna's co-workers and supervisors derided him about his family responsibilities, gave him insufficient work to reach his billable hours quota, and criticized him both for his "tardiness" and for his work performance. ${ }^{81}$ In December 2008, Ayanna was terminated because he failed to meet his billable hours requirement. ${ }^{82}$

73. Id. at 4-5. The court granted summary judgment for the employer on the plaintiff's FMLA interference claim and denied summary judgment on the plaintiff's FMLA retaliation claim. Rasic $v$, City of Northlake, No. 1:08-C-104, 2009 U.S. Dist. LEXIS 88651, at *3 (N.D. Ill. Sept. 25, 2009).

74. Complaint at 2, Carroll v. Tropical Aquaculture Prods., No. 1:08-cv-138 (D. Vt. Mar. 3, 2009), 2008 U.S. Dist. Ct. Pleadings LEXIS 44519.

75. Id. A jury found that the termination was lawful, and the court denied Carroll's motion for a new trial. Carroll v. Tropical Aquaculture Prods., No. 1:08-cv-138, 2009 U.S. Dist. LEXIS 102595, at *1 (D. Vt. Oct. 29, 2009).

76. Complaint and Jury Demand at 1, Ayanna v. Dechert, No. 1:10-cv-12155-NMG, (D. Mass. Dec. 14, 2010).

77. Id. at 4 .

78. Id. at $1-2$.

79. Id at 11 .

80. Id.

81. Id. at $12-13$.

82. Id. at 14 . 
In his complaint, Ayanna targeted the culture at the firm, claiming that he was discriminated against because he did not conform to the "sexist" and "macho" culture. ${ }^{83} \mathrm{He}$ observed that the amount of leave he took "far surpassed the leave any male attorney at Dechert took," 84 and reported that typical male employees "bragged about how little time they spent on family obligations." 85 Ayanna also noticed that women were not treated with the same contempt or disrespect when they engaged in caretaking activities. ${ }^{86}$ His claim crystallized the notion that an important facet of workplace discrimination is to police gender roles and penalize men who undertake responsibilities that are stereotypically assigned to women.

In all of these cases, employers attempt to override the male employee's right to FMLA by calling into question the commitment of the male worker and minimizing the urgency, necessity, and appropriateness of men requesting time off from work to engage in caretaking responsibilities. ${ }^{87}$ Employers may try to deflect the discriminatory behavior by framing the issue as a mismatch between employee and employer, by pointing to business necessity, or by creating "objective" standards of performance that are anything but. ${ }^{88}$ Regardless of the tactic, employers are engaging in discrimination that works to the detriment of both men and women by refusing to let either sex act outside of proscribed patterns.

\section{B. Bad Shifts and Sudden Schedule Changes}

While FMLA interference is a category that encompasses employer behavior before and during the FMLA leave, ${ }^{89}$ retaliation includes the variety of ways in which employers act out against employees when they return from leave. ${ }^{90}$ Most commonly, male employees experience shift

83. Id. at 4.

84. Id. at 11 .

85. Id. at 5.

86. Id. at $7-8$.

87. See cases cited supra notes $67-86$. This is also based on an analysis of cases contained in the Center for WorkLife Law's database of cases. See CALVERT, supra note 54, at 25 (describing the database).

88. See cases cited supra notes 59-62. This is also based on an analysis of cases contained in the Center for WorkLife Law's database of cases. See CALVERT, supra note 54, at 25 (describing the database).

89. Family and Medical Leave Act of 1993 §105(a)(1), 29 U.S.C. $\S 2615(a)(1)$ (2006) ("It shall be unlawful for any employer to interfere with, restrain, or deny the exercise of or the attempt to exercise, any right provided under this title ...."); see, e.g., Strickland v. Water Works \& Sewer Bd., 239 F.3d $1199,1206-07$ (11th Cir. 2001) ("To state a claim of interference with a substantive right, an employee need only demonstrate by a preponderance of the evidence that he was entitled to the benefit denied.").

90. Family and Medical Leave Act of $1993 \S 105(a)(2), 29$ U.S.C. $\S 2615$ (a)(2) ("It shall be unlawful for any employer to discharge or in any other manner discriminate against any individual for 
changes, downgraded schedules, and decreased responsibility. ${ }^{91}$ In an exemplary case, Robert Oest, a male employee at the Bureau of Prisons Federal Correctional Institution in Englewood, Colorado, was "reassigned to a non-equivalent new position while he was on FMLA leave in 2000 for the birth of his second child." 92 Another case involved a delivery supervisor who took FMLA leave following the birth of his daughter. ${ }^{93}$ Upon his return to work, he was assigned to undesirable evening and night shifts that he had never worked before. 94 The employer had a legitimate business reason for the change, as the plaintiff conceded, but the new schedule clearly interfered with the plaintiff's family obligations, and he considered the change a demotion brought on by the company's retaliatory motives. 95 Because the employee provided sufficient evidence of a hostile work environment, the court denied summary judgment for the employer on the plaintiff's FMLA discrimination and retaliation claims. 96

Professionals are not exempt from these types of problems, even though they do not generally have strict shift schedules and do have flexibility in their schedules that low-wage workers do not. In Chin Kuo v. Computer Associates International, Inc., the same type of caregiver discrimination happened to a Senior Vice President and computer software engineer who "had approximately 125 people reporting to him, [and] earned a base salary of $\$ 200,000 .{ }^{\prime \prime 97}$ In this case, Chin Kuo took FMLA leave to care for his newborn son after his wife decided to go back to work. .8 When he returned from leave, he encountered discrimination and hostility. ${ }^{99}$ Kuo was demoted to Vice President, told that he "would no

opposing any practice made unlawful by this title...."); see, e.g., Strickland, 239 F.3d at 1207 ("to succeed on a retaliation claim, an employee must demonstrate that his employer intentionally discriminated against him in the form of an adverse employment action for having exercised an FMLA right").

91. See cases cited infra notes 92-101 and accompanying text. This is also based on an analysis of cases contained in the Center for WorkLife Law's database of cases. See CALVERT, supra note 54, at 25 (describing the database).

92. Oest v. Mukasey, EEOC Appeal No. 0720080041, 2008 EEOPUB LEXIS 3858, at *1-2 (Oct. 8,2008 ). Complainant also claimed that in 1998, his request pursuant to the FMLA for twelve weeks of unpaid leave for the birth of his first child was denied. Id. 2007).

93. Alston v. Sofa Express, Inc., No. 2:06-cv-0491, 2007 WL 3071662, at *2 (S.D. Ohio Oct. 19,

94. Id. at $* 2$.

95. Id.

96. Id. at * $13,{ }^{*} 15$ (" $[\mathrm{T}]$ he affidavits of Bussey and Snowden provide statements which sufficiently controvert the issue of Defendants' motive for reassigning and subsequently terminating Plaintiff. .. . The court finds that Plaintiff's evidence with regard to the reassignment is sufficient to create a genuine issue of material fact as to Defendants' motive for their employment decision.").

97. No. 05-cv-3295, 2007 U.S. Dist. LEXIS 72176, at *4 (E.D.N.Y. Sept. 27, 2007).

98. $I d$. at $* 5$.

99. Id. at *7-8. 
longer be eligible to participate in the Company's incentive compensation plan," and eventually fired. 100 The company argued that Kuo's demotion and termination were part of a larger reduction in force; however, the court found that there was enough correlation in the timing between Kuo's leave and his termination to create questions of fact for a jury. 101

\section{Terminated While on Leave}

In other cases, employees are terminated while on leave. In Wamel $v$. Ocelot Engineering Inc., a technician took FMLA leave to care for his wife, who was ill with cancer. ${ }^{102}$ While he was on leave, his position was eliminated. ${ }^{103} \mathrm{He}$ was subsequently demoted, and, ultimately, he was terminated. ${ }^{104}$ In Fitzpatrick v. Hon Hai Precision Industry Co. Ltd., a Director of Business Development requested and was granted FMLA leave to care for a foster child, but was fired while on leave. ${ }^{105}$ His company claimed that he was downsized in response to changing business needs, but in court he prevailed on his FMLA claim. ${ }^{106}$ Similarly, in Chester $v$. Quadco Rehab Center, a worker in a disability training nonprofit organization had his position eliminated when he took FMLA leave to care for his wife and newborn child. ${ }^{107}$ His employer made the argument-sufficient to prove a legitimate business necessity and to rebut the prima facie case of discrimination - that the company was obliged to lay off employees due to low profits. ${ }^{108}$ However, as the employee David Chester noted in his complaint, the time between the leave and the termination was suspiciously short. ${ }^{109}$ Additionally, Chester contended, his employer threatened him with a bad evaluation if he extended his FMLA leave, and the employer did not announce Chester's termination until after he had requested FMLA leave. ${ }^{110}$ As the court observed:

100. Id

101. Id. at $* 25$.

102. Verdict and Settlement Summary, Wamel v. Ocelot Engineering Inc., No. CIVSS702877, 2008 WL 3166823 (Cal. Super. Ct. July 7, 2008). An arbitrator ultimately found that the employee was wrongfully terminated and that his employer had interfered with his FMLA rights. Id.

103. Id.

104. Id.

105. Verdict and Settlement Summary, Fitzpatrick v. Hon Hai Precision Industry Co. Ltd., No. 06CC02831, 2008 WL 5973828 (Cal. Super. Ct. July 3, 2008).

106. Id. The jury awarded Fitzpatrick $\$ 882,000$. Id.

107. 484 F. Supp. $2 d 735,735$ (N.D. Ohio 2007).

108. Id. at $741-42$.

109. Id.

110. Id. at 739 . 
Another factually similar case is Moorer v. Baptist Memorial Health Care System ... . In Moorer, plaintiff had performance deficiencies severe enough to justify termination, but while the employer was aware of the deficiencies, the employer did not decide to terminate the plaintiff until he took medical leave. ${ }^{111}$

Timing is key. In another case, a Senior Marketing Manager took six weeks of FMLA leave for his child's birth and was terminated while on leave because "management decided to restructure the Marketing and ECommerce Department."112 The district court in this case, Champion $v$. Spencer Gifts, LLC, remarked:

In this case, the preliminary recommendation to terminate Plaintiff was made before he announced his intent to take FMLA leave, but the final decision to terminate Plaintiff's employment was made while he was out on protected FMLA leave, and plaintiff was actually terminated while on that protected leave. The Court is satisfied that the temporal proximity that occurs when an employee is terminated while still engaging in a protected activity is unduly suggestive of a causal connection between the leave and termination. 113

In a particularly egregious iteration of this story, Bell v. Prefix, Inc., the company terminated a male employee while he was taking intermittent FMLA leave to care for his dying father. ${ }^{114}$ In this case, Jonathan Bell, a model maker working in the automotive industry, requested and was granted intermittent FMLA leave to care for his father, who had been diagnosed with an aortic aneurism. ${ }^{15}$ The father was hospitalized on July 22 , 2005 , and surgery was scheduled for the next day. 116 Three days after the surgery, Bell received an emergency call from the hospital, in which he learned that his father's condition had worsened, and that it was urgent that

111. Id. at 741 (citing Moorer v. Baptist Mem'l Health Care Sys., 398 F.3d 469, 490 (6th Cir. 2005)).

112. Champion v. Spencer Gifts, LLC., No. 08-cv-689, 2009 WL 3131461, at *1 (D.N.J. Sept. 24, 2009).

113. Id. at *14 (citing Whitman v. Proconex, Inc., No. 08-2667, 2009 WL 141847, at *12 (E.D. Pa. Jan. 20, 2009) (finding that finalizing a decision to terminate an employee during their FMLA leave, coupled with a firing minutes after returning from leave, is unduly suggestive); Reinhart v. Mineral Tech. Inc., No. Civ.A.05-4203, 2006 WL 4050695, at*11 (E.D. Pa. Nov. 27, 2006) (finding a termination decision unduly suggestive when it occurs twenty-four hours after the FMLA leave ends); Parker v. Hanhemann Univ. Hosp., 234 F. Supp. 2d 478, 492 n.15 (D.N.J. 2002) ("[D]ischarge on the day of plaintiff's return is enough to suggest causation at this prima facie stage of the summary judgment motion.")). "Thus, by showing a causal connection, Plaintiff has satisfied the third requirement and has established a prima facie case of retaliation." Id.

114. Bell v. Prefix, Inc., 321 Fed. Appx. 423, 425 (6th Cir. 2009)

115. Id.

116. Id. 
a family member come to the hospital. 117 Bell asked his supervisor, Jim Turner, if he could leave immediately, and the supervisor requested that Bell stay until noon because it was a particularly busy day. ${ }^{118}$ Bell agreed." 19 Before Bell left, however, the general manager "became enraged and belittled [Bell] in front of Jim Turner and other employees for abandoning [Prefix] when there was work to be done."120 On Monday, August 8,2005 , as Bell continued to take leave to visit his father at the hospital, the general manager discussed Bell's performance with his supervisors, saying, "The attitude that [Bell] has taken probably is a little laxidasical [sic], and the work load was very high and the progress was a little slow."121 The general manager fired Bell the same day. ${ }^{122}$ Six days later, Bell's father died in the hospital.123 The company argued that Bell did not engage in protected conduct because he did not "care" for his dying father as required by the FMLA (he just visited the hospital but did not engage in caretaking). ${ }^{124}$ The court, however, denied Prefix's motion for summary judgment. 125

In these cases of retaliation, employers penalize male employees for taking leave. The employers all articulate legitimate, non-discriminatory reasons for termination. However, the circumstances, the timing, and the anecdotal evidence (typically in the form of hostile remarks) all bring into focus one conclusion - that the employers in question simply disapprove of men undertaking family caregiving responsibilities. These family responsibilities conflict with employers' gendered expectations of the ideal male worker and who is at home attending to the family needs.

\section{Stereotyping and Feminine Men}

While in many cases the stereotyping is subtle (couched in accusations that the plaintiff is a bad worker) or offhand ("we usually don't get a request like this from a man"), other cases showcase blatant and profound stereotyping of men who are caretakers. ${ }^{126}$ In these cases, the stereotyping

117. Id.

118. Id.

119. Id.

120. Id.

121. Id. at 426 .

122. Id.

123. Id. at 425 .

124. Id. at 427.

125. Id. at 431. A jury ultimately returned a verdict for Bell but only found damages of $\$ 14,563$. Bell v. Prefix, Inc., No. 05-74311, 2010 U.S. Dist. LEXIS 112627, at *2 (E.D. Mich. Oct. 22, 2010).

126. See, e.g., Cumbie v. General Shale Brick, 508 F. Supp. 2d 486, 486 (E.D. Va. 2007). 
and discrimination are overt and openly hostile; often, the male employee is subject not only to adverse employment actions but also to ridicule from colleagues and supervisors. ${ }^{127}$ One particularly striking case, Cumbie $v$. General Shale Brick, involved "a fifty-five year old male resident of Prince William County, Virginia, who ha[d] lived with his eighty-seven year old mother for three years." 128 Although Dana W. Cumbie, a truck driver for General Shale Brick, had a good employment record, the general knowledge that he lived with his mother and was her caretaker made him the target of co-worker's ridicule and led to his eventual termination. ${ }^{129}$ The co-workers' hostility was so obvious, pointed, and sexualized that it is worth quoting from the case at length:

Around early May 2003, Plaintiff discovered a drawing ("Drawing One") posted in public view on the bulletin board outside of Rogos' office, presumably depicting Plaintiff on a Harley Davidson motorcycle (which he rode) with his mother as the passenger....

On May 22, 2003, Plaintiff returned to the yard after his shift, only to discover that numerous drawings depicting the same caricature in Drawing One had been posted around the warehouse. The picture ("Drawing Two") depicts Plaintiff on a boat with the caption "Three men and 1 [one] boat ... what could be better?" Another caption points to Plaintiff's backside that reads "butt hurts" with a fifty-five gallon drum of Preparation $\mathrm{H}$ floating nearby in the water.

After discovering this picture, Plaintiff entered the break room and noticed numerous drawings scattered throughout the room, by the entrance, at the coffee pot, and by the refrigerator. Some were identical to Drawing One and Drawing Two, while others represented two new drawings. Of the new drawings, the first ("Drawing Three") depicted the same caricature, presumably Plaintiff, again on his motorcycle, hauling a trailer in a direction opposite to that indicated on a sign with an arrow reading "TO JOB." The second ("Drawing Four") shows the same caricature, again presumably Plaintiff, on a couch next to what appears to be a "penis pump," and a caption above the television reads "And now, the "Dixie Chicks." The man lying on the couch is salivating while sleeping, with a caption above his head that reads, "Huh? What? Chicks with Dix?"'130

The week after Cumbie reported this behavior and showed the drawings to his supervisors, he was informed that he was being suspended for two days without pay for failing to report a workman's compensation claim in a

\footnotetext{
127. See, e.g., id.

128. Id. at 488 .

129. Id. at $488-89$

130. Id. at 488 .
} 
timely manner. ${ }^{131}$ Moreover, Cumbie never again received awards or bonuses for keeping his truck clean, even though he maintained that he kept it in the same condition that he had in the past when he had received merit awards. ${ }^{132}$ Between May and July 2003, Cumbie also complained that he was receiving fewer and shorter daily loads-which translated into less pay. 133

In August 2003, Cumbie took FMLA leave of absence to care for his "ailing mother," and, unbeknownst to him, this turned out to be the end of his employment. ${ }^{134}$ In October 2003, the employer mailed the plaintiff his personal effects but did not otherwise notify him of his termination. 135 Cumbie only learned that he had been fired when he applied for credit to purchase a new motorcycle and was informed that his employment information was incorrect. 136 Despite the rampant hostility that Cumbie encountered from his colleagues and the adverse employment actions he suffered, the court concluded that the drawings constituted nothing more than juvenile and tasteless humor, and found that Cumbie was not covered by any Title VII protection. ${ }^{137}$ Nonetheless, the facts of the case are evidence of the persecution experienced by men who cross gender boundaries, especially when the workplace culture is male-dominated and defined by norms of extreme masculinity.

\section{A "Momcession"? Putting Women BACK INTO the Picture}

Discrimination, loss of status, diminished relevance in the modern marketplace - all of these descriptors became attached to men when the mancession hit. An article in The Atlantic entitled "The End of Men" dramatically declared that fortune's tides were shifting for men: "Man has been the dominant sex since, well, the dawn of mankind. But for the first time in human history, that is changing-and with shocking speed."138

131. Id. at 489

132. Id.

133. Id.

134. $I d$.

135. Id.

136. Id.

137. Id. The court found that:

The drawings posted in Plaintiff's workplace-while offensive, tasteless, and insensitive-could not lead a person to reasonably believe that a Title VII violation has occurred. . . .the Court finds the postings boorish and juvenile, nothing more, and insufficient to rise to the level of leading a person to reasonably believe they are so severe as to be abusive and alter the conditions of employment, constituting a sexually hostile work environment.

Id. at 491-92 (citation omitted).

138. Hanna Rosin, The End of Men, THE ATLANTIC, July/Aug. 2010, http://www.theatlantic.com/magazine/archive/2010/07/the-end-of-men/8135/. 
Speculating about the possibility that women are essentially better suited to the new and emerging needs of a forward-looking, post-industrial economy, the article's author suggested that:

The recession merely revealed-and accelerated-a profound economic shift that has been going on for at least 30 years, and in some respects even longer.... Women dominate today's colleges and professional schools-for every two men who will receive a B.A. this year, three women will do the same. Of the 15 job categories projected to grow the most in the next decade in the U.S., all but two are occupied primarily by women. 139

The article did not question the implication that men's embattlement gave rise to women's empowerment. ${ }^{140}$ Similarly, the article failed to note that, despite impressive female achievement, gender stereotyping continued to hamper the full development and expression of both male and female potential. ${ }^{141}$ Left out of the discussion was the role of the fundamental gender constructs that organize systems of status endowment and economic reward.

\section{A. Ending the Myth of the End of Men}

While the contemplated "end of men" made headlines and the downward plight of males made history, skepticism emanated from feminist quarters. A Newsweek article quoted the economist Heidi Hartmann, who explained the mancession from a different perspective, downplaying women's gains:

The jobs that women are holding on to typically lack benefits, retirement savings plans, or pensions. "The strong part of women's participation in the labor force is also the weak part. Their salaries are limited," says Heidi Hartmann, an economist and president of the Institute for Women's Policy Research. "Women tend to choose a path that's less risky, that's more secure for their families." 142

A blog post by Christopher Swan, stating a similar point, was aptly entitled "The Myth of the Man-cession" and began by pointing out that "recessions are almost always mancessions." $143 \mathrm{He}$ continued by stating

139. Id.

140. See id.

141. See id.

142. Cook, supra note 31 .

143. Christopher Swann, The Myth of the Man-cession, REUTERS (Oct. 6, 2009), http://blogs.reuters.com/columns/2009/10/06/the-myth-of-the-man-cession/; see also Nicole Allan, Have Women Really Taken Over The Workforce?, THE ATLANTIC (Jan. 12, 2010), 
that " $[t]$ he novelty of the mancession has been overstated . . . . Delve deeper, and men have not been doing so badly by historic standards. Nor have women been making great breakthroughs."144 The author also noted that, "[w]hile women have been better at clinging onto their jobs, they have not done so well holding onto their salaries," and that the "gulf between male and female salaries, which narrowed dramatically in the last 25 years, has started to widen again." 145 The conclusion? "Mancession aside, it's still a man's world."146 The Newsweek article echoed this same sentiment, saying, "Most guys, in fact, don't even need rescuing-at least not yet. They're still overrepresented in business and government, earn more on the dollar, open bigger movies, and clean fewer dishes."147

Moreover, the mancession still called on women to do a lion's share of the work. "Women are taking on the responsibility of supporting families as men's jobs have almost disappeared since this recession began."148 While women were more able to hold onto their jobs, given the sectors that were hit by the recession, the recession often left women burdened with being the sole provider. ${ }^{149}$ Studies also found that, while men might have been out of work, the new free time they had was not generally being put to use doing housework or childcare. ${ }^{150}$ "[U]nemployed men are rarely eager to take on women's traditional role in the home," noted Sylvia Hewlett. ${ }^{151}$ Don Peck mentioned "economists George Akerloff and Rachel Kranton find that among married couples, men who aren't working at all, despite their free time, do only 37 percent of the housework, on average. And some

http:/www.theatlantic.com/business/archive/2010/01/have-women-really-taken-over-the-

workforce/33314/.

144. Swann, supra note 143.

145. Id.

146. Id.

147. Andrew Romano \& Tony Dokoupil, Men's Lib, NEWSWEEK (Sept. 20, 2010), http://www.newsweek.com/2010/09/20/why-we-need-to-reimagine-masculinity.html.

148. Boushey, supra note 26 , at 2 .

149. Id.

150. Sarah Baxter, Women are Victors in 'Mancession,' THE SUNDAY TIMES (June 7, 2009), http://www.timesonline.co.uk/tol/news/world/us_and_americas/article6445913.ece.

151. Id. However, the article does mention a number of men who buck this trend and are willing to engage in role reversal after losing a job:

Rhett Rhame, a father of three young children, found himself in the role of "Mr Mom" when he lost his post as a salesman with a fire sprinkler company in Georgia. His wife works as the director of the local education authority. "I have no problem with picking up my wife's drycleaning," he said. "I just do what needs to be done, and quite honestly I feel really lucky to have this time with the kids." 
men, apparently in an effort to guard their masculinity, actually do less housework after becoming unemployed."152

A New York Daily News article title summed it up: "Working moms more overburdened than ever during the 'mancession'; out-of-work hubbies add to woes." 153 The article found that "[w]omen don't only work long hours at their jobs and then care for the kids once they get home. They're also facing longer hours and more responsibilities as they assume the tasks that formerly employed colleagues once performed."154 Unpacking the pieces of the phenomenon from the working woman's perspective, and coining a term meant to counter "mancession," a Forbes blog post wondered if, instead of being a mancession, the current downturn wasn't really a "momcession."155 In fact, a study from Citi in 2009 found that "the recession is taking a big toll on working moms," and reported that:

Over half of the 1,000-plus women surveyed reported working longer hours, while just one in four women without children and one in three men reported doing so. Meanwhile, working moms have also adjusted their spending more than other groups: Three in four said their habits are forever changed, compared to six in ten women without children. 156

If the recession put mothers under pressure, single mothers-as usualwere the canary in the mine: one study concluded that "[s]ingle mothers were hit particularly hard by the recession."157

152. Peck, supra note 6. The Newsweek article "Men's Lib" also noted that:

[S]ome men have turned to old models and mores of manhood for salvation. . . the term "retrosexual" has all but replaced "metrosexual" in the lifestyle sections of national magazines, which are full of stories about affluent urbanites wearing hunting garb, buying designer axes, and writing about the art of manliness on blogs with names like (ahem) the Art of Manliness. . , , A rapper's saggy jeans, a hunter's concealed weapon, a suburbanite's man cave, a hipster's obsession with Don Draper: all might be seen as variations of the same coping mechanism. Romano \& Dokoupil, supra note 147.

153. Rosemary Black, Working Moms More Overburdended Than Ever During the 'Mancession'; Out-of-Work Hubbies Add to Woes, NY DAILY NEWS (Jan. 26, 2010), $\mathrm{http}: / /$ www.nydailynews.com/lifestyle/2010/01/26/2010-01-26_with_more_men_out_of_work working_moms_suffer_through_the_mancession_html.

154. Id.

155. Jenna Goudreau, Mancession or Momcession?, FORBES.COM, (May 11, 2010, 11:41AM), $\mathrm{http} / / /$ blogs.forbes.com/work-in-progress/2010/05/11/jobs-recession-economy-women-earningsmancession-momcession/.

156. Kimberly Palmer, Working Mothers Hardest Hit by Recession, U.S. NEWS \& WORLD REPORT (Oct. 14, 2009), http://money.usnews.com/money/blogs/alpha-consumer/2009/10/14/working-mothershardest-hit-by-recession.html.

157. Goudreau, supra note 155 ("Without a spouse's earnings to fall back on, job losses among single moms were a huge blow to many families. Their unemployment rate rose from $8 \%$ in 2007 to about $14 \%$ in 2009. Single moms of children under 6 faced an unemployment rate of $17.5 \%$ in 2009 . Furthermore, 3.3 million women were forced to take part-time employment for economic reasons, a particular hardship for mothers. Lower earnings, lack of benefits, limited vacation or sick leave and the high costs of part-time childcare came together to create devastating effects for millions of families."). 
What stories about the "mancession" did not discuss was the persistence of gender stereotypes about women and, most especially, mothers. While men with caretaking responsibilities were sanctioned for gender nonconformity, career women were sanctioned for gender conformity. Despite women's much touted and recession-induced dominance in the labor market, and the reality of "a long-run trend of women's earning becoming more and more important to their family's economic well-being,"158 many employers continued to see mothers as inauthentic and non-committed workers. Put another way, men were penalized for being caretakers, while women were penalized both for being workers and for being caretakers. More generally, while men are often penalized for straying from the provider role, once women become mothers, many encounter workplace penalties no matter how they behave. This point was proved when a leading 2007 study gave subjects resumes that were identical except in one respect-one resume, but not the other, mentioned membership in the PTA. ${ }^{159}$ The mothers were seventy-nine percent less likely to be hired, onehundred percent less likely to be promoted, offered $\$ 11,000$ less in salary, and held to higher performance and punctuality standards. ${ }^{160}$

These biases are visible in the female FRD cases that make it into court. In female FRD cases, patterns of discrimination include the following workplace penalties for mothers and pregnant women: failure to hire, 161 being singled out for increased scrutiny, ${ }^{162}$ being denied benefits, ${ }^{163}$ failure to promote, ${ }^{164}$ hostile work environments, ${ }^{165}$ and wrongful termination. ${ }^{166}$

158. Boushey, supra note 26 , at 2 .

159. See Shelley J. Correll, Stephen Benard \& In Paik, Getting a Job: Is There a Motherhood Penalty?, 112 AM. J. OF Soc. 1297, 1329 (2007).

160. Id. at 1316,1329 .

161. See, e.g., Carter v. Shop Rite Foods, Inc., 470 F. Supp. 1150, 1151 (N.D. Tex. 1979) (employer refused to hire women for managerial positions because of their child care responsibilities).

162. See, e.g., Walsh v. Nat'l Computer Sys., Inc., 332 F.3d 1150, 1154-55 (8th Cir. 2003) (female employee experienced hostility and increased scrutiny from her supervisor when she returned from maternity leave); Sackett v. ITC Deltacom, Inc., 374 F. Supp. 2d 602, 606 (E.D. Tenn. 2005) (employer began hyper-scrutinizing salesperson's work after she became pregnant); Stansfield v. O'Reilly Auto, Inc., No. H-04-4161, 2006 WL 1030010, at *3 (S.D. Tex. Apr. 19, 2006) (supervisor forbade pregnant woman from asking for help when lifting heavy objects despite encouraging males to ask for assistance).

163. See, e.g., Ryl-Kuchar v. Care Centers, Inc., 565 F.3d 1027, 1029 (7th Cir. 2009) (employer cancelled employee's group health insurance after she took FMLA leave); EEOC v. Bell Atlantic Corp., No. 97 Civ. 6723, 2002 U.S. Dist. LEXIS 19156, at*1-3 (S.D.N.Y. Oct. 9, 2002) (female employees were denied service credit toward pensions when they took time off for pregnancies or to care for children).

164. See, e.g., Lettieri v. Equant, Inc., 478 F.3d 640 (4th Cir. 2007) (sales director denied promotion because of child care responsibilities); Coble v. Hot Springs Sch. Dist. No. 6, 682 F.2d 721, 726 (8th Cir. 1982) (female teacher was excluded from promotion because she was a woman with children); Trezza v. The Hartford, Inc., No 98 CIV 2205(MBM), 1998 WL 912101, at *1-2 (S.D.N.Y. Dec. 30, 1998) (female attorney who had children not promoted to management position that required frequent 
In addition to these suits, which women typically file under Title VII, women also file a large number of FMLA claims for interference and/or retaliation with family and medical leave. ${ }^{167}$

\section{B. Don't Tell the Boss You're Pregnant}

Like men in similar situations, women with family responsibilities often are assigned undesirable shifts, underpaid, given different workplace responsibilities in order to effectively demote them, and blocked from promotion prospects. Women, however, often experience these changes in the terms of their employment even upon telling their supervisors that they are pregnant. In fact, in EEOC v. Menard Inc., discrimination against the female employee began when she told her supervisor that she had decided to undergo the process of in-vitro fertilization. ${ }^{168}$ Less than two weeks after having a surgical procedure related to the in-vitro fertilization, Coe was demoted because the company was "questioning the leadership in the Wall Coverings Department."169 Discussing the demotion, Coe's supervisor "told her that he did not feel that the Wall Coverings Department was working well together as a team" and that her demotion and transfer to the Plumbing Department would be good for her. ${ }^{170}$ The demotion came with more than a mere shift in department: "Coe's pay went from $\$ 11.40$ per hour to $\$ 9.75$ per hour. She also lost two annual cost-of-living raises for the previous two years that she was a manager and two merit raise increases." 171 Coe voluntarily resigned from Menard several months later and filed suit. ${ }^{172}$ The court denied summary judgment for Menard, finding that there were genuine questions about the reasons for Coe's demotion and the timing of the company's decisions. ${ }^{173}$

travel because employer assumed position would interfere with caretaking responsibilities); Moore v. Alabama State Univ., 980 F. Supp 426, 431 (M.D. Ala. 1997) (employee was passed over for promotion because she was married and pregnant).

165. See, e.g., Walsh, 332 F.3d at 1154-55 (8th Cir. 2003) (female employee experienced hostility from her supervisor, who threw telephone book on her desk with a direction to find a pediatrician who was open after hours when employee requested leave to pick up sick child from daycare).

166. See, e.g., Sheehan v. Donlen Corp., 173 F.3d 1039, 1043 (7th Cir. 1999) (female accounts manager with three children terminated and told "[h]opefully this will give you some time to spend at home with your children").

167. See CALVERT, supra note 54, at 11 (describing the laws used in FRD cases).

168. No. 08-0655-DRH, 2010 WL 331729, at *2-3 (S.D. Ill. Jan. 22, 2010).

169. Id.

170. $I d$. at $* 2$.

171. Id. at *3.

172. Id.

173. Id. at *7. 
The wide range of adverse employment actions that women encounter before even giving birth is illustrated again in Starr v. Oceaneering International, Inc. ${ }^{174}$ Even before Starr, a data entry clerk, announced her pregnancy, she had a difficult relationship with her supervisor. ${ }^{175}$ Starr's supervisor once asked her, in relation to another female employee, "What's that cunt doing in here?"176 The same supervisor sent Starr and other employees an email with sexually explicit paraphernalia and commentary. ${ }^{177}$ When Starr told her supervisor she was pregnant, he said, "Sucks for you," before checking his reaction and commenting, "I guess what I should have said was congratulations."178 Starr encountered more than just hostile reactions and inappropriate comments from her supervisor. Just before Starr took her FMLA leave, she asked her assistant to complete a task. ${ }^{179}$ The assistant did not respond, and Starr later received an email from a coworker stating that the supervisor had changed things in the office. ${ }^{180}$ Subsequently, while Starr was on FMLA leave, she received an email instructing her that she and other employees whom she had previously supervised were to report to a new supervisor. ${ }^{181}$ Unable to return to work on the agreed upon date because she had not been released by her doctor, Starr returned to work two weeks later to find her position had been eliminated. 182

Discrimination upon the announcement of pregnancy does not come solely in the form of hostility from male supervisors. In Holland v. Gee, a female supervisor helped to make the decision to transfer a pregnant female employee from her position as a data technician to a spot at the help desk. ${ }^{183}$ The supervisor testified in court that she did so because she "felt it was a nice thing to do" and because she "personally thought if I were pregnant, I would prefer to work on the help desk as opposed to the job as a technician."184 The company later transferred the employee back to her original position, but subsequently refused to "honor her doctor's note

174. No. 4:09-cv-0204, 2010 WL 644445 , at * 1 (S.D. Tex. Feb. 18, 2010).

175. Id.

176. $I d$.

177. Id.

178. $I d$.

179. Id. at *2.

180. Id.

181. Id.

182. Id. at *3. The company contended that Star's position had been eliminated due to cost savings initiatives. Id. The Company also claimed that there were no positions at Oceaneering that Starr was qualified for that paid the same salary she received before going on FMLA leave. Id. Oceaneering did offer Starr a position as a Senior Data Processor at a salary of around \$18 per hour that she did not accept, at least partly because of the substantial reduction in pay. Id.

183. 719 F. Supp. 2d 1361, 1363 (M.D. Fla. 2010).

184. Id. at 1364 . 
[about lifting restrictions] because Plaintiff did not provide restrictions in her own words." 185 The court denied summary judgment for the company and noted that a reasonable jury could find the company's arguments "unworthy of credence."186 What all of these cases illustrate is that women experience hostility in the workplace as soon as they become pregnant, and, once they make the pregnancy known, they experience workplace discrimination in multiple ways.

\section{Hyperscrutiny and Invented Expectations}

Although workplace discrimination may begin the moment a female employee announces her pregnancy, it certainly does not stop there. Once women become pregnant and are marked as mothers, they continue to suffer from a range of discriminatory employment practices. These practices mirror those directed against men, although the trigger incidents are sometimes different since they involve not only actual caretaking demandse.g., time off for childcare 187 or eldercare ${ }^{188}$ - but also issues that arise related to pregnancy and birth-e.g., pregnancy restrictions, ${ }^{189}$ requests for light duty, ${ }^{190}$ time off for childbirth, ${ }^{191}$ and breast feeding. ${ }^{192}$ Regardless of the particulars of the employee requests, the results are the same, and include denying benefits, ${ }^{193}$ instigating transfers, ${ }^{194}$ and withholding promo-

185. Id.

186. Id. at 1369 .

187. See, e.g., Sheehan v. Donlen Corp., 173 F.3d 1039, 1043 (7th Cir. 1999) (female manager with three children terminated and told she could spend more time at home with children); Eslinger v. U.S. Cent. Credit Union, 866 F. Supp. 491, 494 (D. Kan. 1994) (female employee was terminated after taking maternity leave and additional time off to care for her two children).

188. See, e.g., Lucke v. Multnomah Cnty., No. CV-06-1149-ST, 2008 U.S. Dist. LEXIS 71861, at *119-20 (D. Or. Sept. 22, 2008) (denying summary judgment for defendant employer on plaintiff's FMLA interference claim where female employee was transferred and demoted after she took leave to care for her terminally ill father)

189. See, e.g., EEOC v. Horizon/CMS Healthcare Corp., 220 F.3d 1184, 1188-89 (10th Cir. 2000) (pregnant employees were denied requests for modified duty after being put on work restrictions by their physicians)

190. See, e.g., Stansfield v. O'Reilly Auto, Inc., No. H-04-4161, 2006 WL 1030010, at *3 (S.D. Tex. Apr. 19, 2006) (supervisor forbade pregnant woman from asking for help when lifting heavy objects despite encouraging males to ask for assistance).

191. See, e.g., Valentine v. Legendary Marine FWB, Inc., No. 3:09cv334/MCR/EMT, 2010 U.S. Dist. LEXIS 40425, at *11-14 (N.D. Fla. Apr. 26, 2010) (female employee brought claim for discrimination under Title VII and interference with FMLA rights after being terminated while on maternity leave).

192. See, e.g., Dep't of Fair Emp't and Hous. v. Acosta Tacos, No. E200708 T-0097-00se, 2009 WL 2595487, at*1 (Cal. Fair Empl. and Hous. Comm'n June 19, 2009) (holding that refusal to allow employee to return to work from pregnancy disability leave because she was still breast feeding was discrimination on the basis of sex in violation of state law).

193. See cases cited supra note 163. 
tions. ${ }^{195}$ In addition, employers often have different, higher standards for caretakers, hyper-scrutinizing their work or creating new standards and job expectations in order to penalize the employee. 196 Often, the increased monitoring, new performance expectations, and intense scrutiny are done with the intent of finding grounds for termination; however, hyper-scrutiny constitutes retaliation whether or not the employer is actively seeking a rationale for termination. 197

A 2005 case, Sackett v. ITC Deltacom, Inc., illustrates how hyperscrutiny operates. ${ }^{198}$ A salesperson at a cell phone company became pregnant and her supervisor's attitude towards her changed almost immediately after he learned of the pregnancy. ${ }^{199}$ According to Sackett's testimony, the supervisor called her into his office, locked the door, and yelled at her, questioning her about potential child care arrangements and demeaning her because she did not have full custody of her first child. ${ }^{200}$ Sackett also testified that she was singled out during sales meetings and placed on a "performance improvement plan" that deviated from company's standard plan, containing sales goals that were practically unattainable. 201 When it appeared that Sackett would meet the goals, her supervisor increased them again. ${ }^{202}$ Approximately four months after she was hired, and while she was participating in the performance improvement plan, Sackett was terminated. ${ }^{203}$ Her subsequent Title VII claim went before a jury, who found for Sackett and awarded compensation for pain and suffering and backpay. ${ }^{204}$

In a more recent case from 2009 , the issue of breastfeeding was the pivot that created both the friction as well as the legal claim, demonstrating

194. See, e.g., Lawson v. Plantation Gen. Hosp., L.P., 704 F. Supp. 1254, 1268 (S.D. Fla. 2010) (holding that genuine issue of material fact existed as to whether employer's transfer of plaintiff from administration position to medical staff constituted adverse employment action in retaliation for taking medical leave).

195. See cases cited supra note 164.

196. See cases cited supra note 162.

197. See Walsh v. Nat'l Computer Sys., Inc., 332 F.3d 1150, 1154-55 (8th Cir. 2003) (female employee experienced hostility and increased scrutiny from her supervisor when she returned from maternity leave); Brissette v. Franklin Cnty. Sheriff's Office, 235 F. Supp. 2d 63, 81-82 (D. Mass. 2003) (Title VII case holding that employer's hyper-scrutiny of female employee's work constituted evidence of retaliation); but see Von Gunten v. Maryland, 243 F.3d 858, 869-70 (4th Cir. 2001) (holding that employer's hyper-scrutiny of sick-leave requests did not amount to retaliatory or hostile work environment).

198. 374 F. Supp. 2 d 602, 606 (E.D. Tenn. 2005).

199. Id. at 606.

200. Id.

201. Id

202. Id.

203. Id. Id.

204. Id. at 604 . The jury awarded Sackett $\$ 20,000$ for pain and suffering and $\$ 15,000$ for backpay. 
how an employer can create inappropriate-and often illegal-rules to target a caretaker. ${ }^{205}$ In this case, Department of Fair Employment and Housing v. Acosta Tacos, Marina Chavez was working as a swing-shift cashier at a taco restaurant when she became pregnant. ${ }^{206}$ After delivering her baby and being placed on pregnancy disability leave, Chavez called her employer, only to find that he had filled her position. ${ }^{207} \mathrm{Her}$ boss told her that he would try to find her another position, and shortly after that he asked her to work the swing shift to cover for an absent employee. ${ }^{208} \mathrm{Cha}$ vez worked that night from 5:00 p.m. to midnight, and, during her halfhour lunch break, her partner brought their newborn baby to the workplace so that Chavez could nurse the baby in the car. ${ }^{209}$ The next night on the same shift, the restaurant owner called and asked to speak with Chavez, telling her that he had learned that she had breastfed her baby the prior night, and stating that she could not breastfeed during her breaks. ${ }^{210}$ When Chavez objected, the owner told her that he could no longer use her and fired her. ${ }^{211}$ A California court found for Marina Chavez and awarded her damages for backpay and emotional distress. 212

Hyperscrutiny is an issue with respect to care of adults as well as care of children. In a case about eldercare and spousal care that highlights that caretaker discrimination is not limited to mothers, a Human Resources manager at a metal products company was terminated with little-to-no understanding of the specific cause for the termination. ${ }^{213}$ Jodie Detwiler, the plaintiff, requested intermittent FMLA leave when her father was diagnosed with lung cancer and when her mother, who had congestive heart failure, underwent heart surgery. ${ }^{214}$ During the same period, Detwiler's husband was diagnosed with amyloidosis, a serious and fatal disease that

205. Dep't of Fair Emp't and Hous. v. Acosta Tacos, No. E200708 T-0097-00se, 2009 WL 2595487, at *1 (Cal. Fair Empl. and Hous. Comm'n June 19, 2009) Chavez stated a claim of pregnancy discrimination falling under the California Fair Employment and Housing Act and her employer was ordered to immediately cease and desist from denying any employee's right to a discrimination-free work environment based on sex or pregnancy, develop and implement a written policy prohibiting sex and pregnancy discrimination in the workplace, and disseminate that policy, develop a complaint procedure, and provide training on that policy. Id. at *13. Chavez was awarded $\$ 20,000$ for emotional damages and $\$ 21,645$ in backpay; the restaurant was also ordered to pay a $\$ 5 \mathrm{k}$ administrative fine. Id.

206. Id. at *3.

207. Id.

208. Id.

209. Id.

210. Id.

211. Id.

212. Id. at $* 13$.

213. Detwiler v. Clark Metal Prods. Co., No. 08-1099, 2010 U.S. Dist. LEXIS 36896, at *34-36 (W.D. Pa. Mar. 19, 2010).

214. Id. at *13-14. 
required care. ${ }^{215}$ The company agreed that some of the absences Detwiler took to tend to her father's medical condition were covered by the FMLA (and, in fact, could not identify any specific instances when she took off work to care for her family that were not covered by the FMLA). ${ }^{216}$ Detwiler stated she tried to use her FMLA leave sparingly so that she could fulfill her work responsibilities, and her supervisors fully acknowledged that Detwiler kept them advised of her husband's and her parents' medical conditions. ${ }^{217}$ While on FMLA leave, Detwiler kept her laptop with her and even worked from the hospital while her husband underwent a stem cell transplant. 218 During this time, Detwiler worked on job descriptions and personality testing projects and kept in contact with the office through email. ${ }^{219}$ Nonetheless, the company terminated Detwiler, and, when she asked her supervisor for a reason, Detwiler was told that "she knew why." 220 When pressed for a reason, Detwiler's supervisor finally told her that other employees had complained about her absenteeism, that she made mistakes at work, and that she had become "an island." 221 Finding that the circumstances of the termination created genuine issues of fact, and making reference to "inappropriate criticisms" from Detwiler's supervisors, the court denied summary judgment for the employer. ${ }^{222}$

\section{Persistent Assumptions About Mothering and Work}

Female, like male, employees with caretaking responsibilities continue to be subject to deeply entrenched, yet capacious stereotypes that undergird and shape employment practices. Stereotyping impacts men and women differently, however, proscribing different norms for each gender-men are penalized for deviating from the ideal worker norm, while women are judged negatively for trying to adopt and inhabit the ideal worker persona. Nonetheless, stereotyping converges around caretaking. Caretaking transcends sex and focuses on the gendering of specific responsibilities, such as childcare, and of personal qualities, such as compassion. In the workplace, therefore, male caretakers are feminized before being subjected to discrim-

\footnotetext{
215. Id. at *14.

216. Id. at *15.

217. Id.

218. Id. at * $* 15-16$.

219. Id. at *16.

220. Id. at $* 35$.

221. Id. at *35-36.

222. Id. at 83-85.
} 
ination, and female caretakers are punished not for being mothers, per se, but for being working mothers.

A blatant example of the stereotyping that affects working mothers is Gerving v. Opbiz, $L L C$, in which a female casino worker was terminated for supposedly poor performance.223 Although the defendant did allege facts that raised genuine concerns about the employee's performance, there was also significant evidence of discrimination: The plaintiff's supervisor allegedly remarked that women were equal to men only until they became mothers and that, once they became working mothers, women were unable to meet the same performance standards as men or as women with no children. ${ }^{224}$ The supervisor also told the plaintiff that a mother's place was in the home. 225 The Ninth Circuit found that a reasonable jury could find that the "termination was motivated by discriminatory animus" and remanded the case. 226

Subtle or not, these actions all show a widespread, hostile attitude toward women who are both workers and caretakers, and reinforce notions of the appropriate female role and sphere. The discrimination comes not only from male supervisors, but also from their female counterparts. In the case of Niedzwiedz v. Napolitano, a Border Patrol Agent alleged that she was subjected to discriminatory harassment because of her gender and because she was pregnant. ${ }^{227}$ Priscilla Niedzwiedz's supervisor, who was a woman, allegedly said, "I understand you became pregnant during your probationary period. So while your classmates were out there working the field, you were working inside, pregnant. They were working out there, earning their reputation while you were pregnant and your job was handed to you."228 Picking up on the often-repeated themes of irresponsibility and laziness, this female supervisor reinforced notions about the incompatibility of work and motherhood. Although the court did not find that this treatment rose to the level of a hostile work environment, it did find that the remarks made by the supervisor "were sufficiently severe to state a claim of discriminatory harassment."'229

Other patterns of discrimination, hearkening back to seminal cases like $E E O C$ v. Sears Roebuck \& Co., ${ }^{230}$ are deeply systemic and encompass

223. 324 Fed. Appx. 692, 694 (9th Cir. 2009).

224. Id.

225. Id.

226. Id. at 695 .

227. EEOC Appeal No. 0120102859, 2010 EEOPUB LEXIS 2832, at *1 (EEOC Sept. 24, 2010).

228. Id. at $* 2$.

229. $I d$. at $* 5$.

230. 628 F. Supp. 1264,1278 (N.D. Ill. 1986). 
unique instances of discriminatory treatment as well as a range of employment practices, from hiring to promotion. Often, discriminatory employment practices are based on the company management making assumptions about what kind of work women prefer, 231 what kind of schedules best accommodate the role of mother, ${ }^{232}$ how willing women are to move for a job, ${ }^{233}$ and how many hours they are willing to work. ${ }^{234}$ Sometimes assumptions remain implicit, articulated only in negative actions and indirect remarks. More often than not, however, the discriminatory presumptions made by the employer are clearly expressed through blatant remarks and adverse employment actions.

\section{E. Patterns and Practices: The Case of Novartis and the Class Action Suit}

An exemplary case of discriminatory patterns and practices is Breeden v. Novartis Pharmaceutical Corp. 235 When Mary Kate Breeden, a salesperson in Novartis's transplant business unit, notified her employer of her pregnancy and her intention to take leave, consultants noted her pregnancy on PowerPoint slides used for planning the realignment of sales territories. ${ }^{236}$ When Breeden objected to any change to her territory, the general manager of her unit responded, "Well, you're not coming back from maternity leave anyway, right?"237 When Breeden did in fact return from maternity leave, her territories had been changed and reduced. ${ }^{238}$ The court agreed that the timing between her pregnancy and the reduction was close

231. See, e.g., Trezza v. The Hartford, Inc., No 98 CIV 2205(MBM), 1998 WL 912101, at *1-2 (S.D.N.Y. Dec. 30, 1998) (female attorney who had children not promoted to management position that required frequent travel because employer assumed position would interfere with caretaking responsibilities).

232. See, e.g., Santiago-Ramos v. Centennial P.R. Wireless Corp., 217 F.3d 46, 50 (1st Cir. 2000) (female director of finance and administration who worked forty-plus hours per week, had one child, and was planning on having a second child was repeatedly asked if could handle her job and child care simultaneously).

233. See, e.g., Dukes v. Wal-Mart Stores, Inc., 222 F.R.D. 137, 152 (N.D. Cal. 2004), aff'd, 474 F.3d 1214 (9th Cir. 2007), reh'g en banc, 603 F.3d 571 (9th Cir. 2010), cert. granted, 131 S. Ct. 795 (2010) (one of the requirements for promotion to management at Wal-Mart was that the employee be willing to relocate to different geographic locations, and class action plaintiffs alleged that this policy had a disparate impact on women).

234. See, e.g., Back v. Hastings on Hudson Union Free Sch. Dist., 365 F.3d 107, 130 (2d Cir. 2004) (holding that employer's belief "that women with young children in fact should not or would not work long hours ... cannot serve as a refuge in the discrimination context").

235. 684 F. Supp. $2 d 58,58$ (D.D.C. 2010)

236. Id. at 60 .

237. Id.

238. Id. at $62-63$. 
enough to create a genuine issue of material fact and, therefore, to allow her case to withstand summary judgment. ${ }^{239}$

This case was made all the more salient by another decision against Novartis in Velez v. Novartis Pharmaceuticals Corp. ${ }^{240}$ In Velez, after "seven years of litigation and the seven weeks of trial, a nine-member jury ... awarded $\$ 250$ million in punitive damages to the Class as a whole," and awarded $\$ 3.36$ million in compensatory damages to the twelve testifying witnesses. ${ }^{241}$ Making clear that what happened to Mary Kate Breeden was not just an outlying instance of discrimination, the Velez suit uncovered firmly entrenched systems designed to penalize women who tried to succeed in the workplace. ${ }^{242}$ Although the magazine Working Mother listed Novartis as a "top company to work for" in recognition of the company's work-life policies, ${ }^{243}$ the pregnant women and mothers working at Novartis found that the formal policies did not prevent pregnant women and women with children from being harassed and unlawfully terminated. 244

During the protracted legal battle, the plaintiffs, on behalf of more than 6,000 potential female claimants, alleged that they had been subjected to gender hostility and retaliation, and discriminated against in promotions, pay, and treatment. ${ }^{245}$ The plaintiffs claimed, "the overwhelming subjectivity inherent in Novartis' compensation policies combined with the exploitable gaps in those policies allow managers almost total discretion to discriminate against employees in compensation on the basis of their gender."246 The plaintiffs also alleged discrimination based on pregnancy and motherhood, claiming that women were fired while on maternity leave and mocked by supervisors if they were visibly pregnant. ${ }^{247}$

239. Id. at 63 .

240. No. 1:04-cv-09194-CM, 2010 U.S. Dist. LEXIS 125945, at *1 (S.D.N.Y. Nov. 30, 2010).

241. $I d$. at $* 10$.

242. See id. at *24-30 (holding that the class of more than 6,000 female Novartis employees met the requirements for certification as a class in part because they shared the common allegation that Novartis "favored male sales force employees over females in compensation and promotion and that Novartis favored non-pregnant sales force employees over pregnant sales force employees").

243. Working Mother 100 Best Companies 2009: Novartis Pharmaceuticals, WORKING MOTHER, http://www.workingmother.com/BestCompanies/work-life-balance/2009/08/novartis-pharmaceuticals (last visited Feb. 15, 2011).

244. Velez, 2010 U.S. Dist. LEXIS 125945, at *29.

245. Id. at *7-8.

246. Id. at 7 .

247. Plaintiff's Proposed Finding of Facts and Conclusions of Law at 95, Velez v. Novartis Pharms. Corp., No. 1:04-cv-09194-CM, (S.D.N.Y. May 13, 2010), Document 290. 
Pregnancy discrimination is, in fact, one of the most important categories named in the plaintiffs' complaint. ${ }^{248}$ Pregnant women, plaintiffs claimed, were terminated, retaliated against, and denied promotions and transfers soon after announcing their pregnancies or giving birth. ${ }^{249}$ As one sales manger testified, "If a manager wanted to terminate a (pregnant) sales representative, it would be fairly easy to build a record of problems and shortcomings that could be used against that representative."250 Female employees also understood that taking time off work for childbearing was frowned upon. ${ }^{251}$ The actions of individual managers reinforced those perceptions. In one instance, a "District Manager sent out [an email] listing sales representatives taking pregnancy leave as a problem in his district," 252 and, in another, the "District Manager told [an employee] that if she took off the full twelve weeks that she was requesting for maternity leave, he might not be able to give her a good review when she returned to work."253 When Sean Bogdany applied for employment with Novartis, managers told him that he needed to be patient because they were working on removing a pregnant woman from the territory. 254 Specifically, the Novartis managers were trying to make the pregnant female employee quit by moving her to another territory. 255

At the close of the jury trial, the jury found that Novartis had discriminated against all class members-female sales representatives, district managers, and area sales managers - in decisions regarding pay and promotion and with respect to the terms and conditions of their employment. ${ }^{256}$ After the verdict, the parties settled the case for $\$ 152.5$ million. 257 The settlement agreement also included a very detailed program to combat discrimination within Novartis. 258 Settlement terms mandated the creation of work-life and leave surveys, changes to and monitoring of the promotions system, the establishment of sexual harassment training, a restructuring of the Human Resources Office, and the implementation of new Human

248. Id. at $98-123$.

249. Id. at 96 .

250. Id.

251. Id. at $103-23$.

252. Id. at 106.

253. Id. at 121 .

254. Id. at 104 .

255. Id.

256. Velez, 2010 U.S. Dist. LEXIS 1259445, at*11-12.

257. Id. at *14-15.

258. Id. at *13-17. 
Resources policies designed to facilitate complaints and increase the resources dedicated to investigating complaints. 259

Although class action FRD litigation presents thorny issues of commonality, numerosity, and claimant identification, Velez provides a roadmap for plaintiffs' lawyers about how to litigate a FRD claim on behalf of a class. Additionally, because of the extended reach and scope of a class action claim, the case has important implications for employers. In many respects, Velez successfully challenged a particular corporate culture and the sex-based biases embedded in that culture that derailed women's advancement. Looking to the future, and taking note of the Novartis example, employers will be well advised to look closely at whether women are making it to the top levels of management in their companies. If women are not making their way up the corporate ladder and thriving at top levels, an employer will no longer be able to take refuge in the argument that corporate culture is beyond the reach of change. Equally important, the Velez case sends a clear message that policies alone are not enough (Novartis had plenty of policies)-what matters is how the policies are carried out in practice.

\section{SUPPORTING CARETAKERS: THE "NEW MACHO" AND FAMILY- FRIENDLY WORKPLACES}

What starts in public discourse with the discussion of mancession and transforms into suggestion of momcession is, at bottom, an old conversation about the right to employment, workplace privilege, and the perpetual historical impulse to both segregate the workplace from the home and segregate within the workplace by gender. The mancession discourse demonstrates that unemployment is considered a greater problem when it is men who are unemployed. The momcession intervention offers a critique of this focus on men's "down and out" moment by reminding us of the myriad ways in which women continue to be denied equal rights in the workplace on a daily basis. Both discourses, however, illustrate the resilience of prescriptive gender stereotypes and their continued ability to order both private and public spheres, delineating the appropriate sets of concerns for men and women. The two discourses illustrate what is problematic is not just male unemployment or pay disparity for women but also, more broadly, the gendering of caretaking and the negative assessment of the feminine in the workplace. Men and women alike suffer from the illicit association 09194-CM (S.D.N.Y. July 14, 2010), Document 294-2. 
of carework with feminine concern and the circumscription of carework to the home, exclusive of the working world.

A first problem with this framework - the devaluation of the feminine and the exclusion of caretakers from meaningful employment-is that it is unresponsive to the changes in the market and workplace. The mancession debate, in decrying the effect of recession on male employment, indirectly highlights the possibility that the breadwinner ideal is an historical artifact, left in shambles by decreased real earnings and a continuing drop in purchasing power. Men can no longer deliver on the promise to support a family in the way they used to:

For two generations after World War II, a blue-collar man could support his family; buy a house, car and washing machine; and send his kids to good public schools.... Then the economy shifted. The wages of highschool-educated men fell by nearly a fourth in the 1980s and 1990s. Family income fell less, but only because families sent wives into the labor force. ${ }^{260}$

Workplace stereotypes have yet to catch up with this reality, and these stereotypes, both descriptive and prescriptive, still sanction men for not living up to the breadwinner ideal, while sanctioning women who try to attain it.

Another problem with stagnant concepts of workplace gendering, flagged by the mancession/momcession debate, is that these concepts are unsustainable given the current move away from certain labor markets, like heavy industry, and towards new markets that focus on knowledge work and technical expertise. Men will benefit in the future by moving out of traditionally male-dominated fields-fields that are currently in decline and were the cause of the mancession. A Newsweek article, aptly entitled "Men's Lib," put it this way:

[A]s women assume positions once occupied exclusively by men, and the more 'manly' sectors of the U.S. economy continue to shrink, a more capacious notion of manhood- the product of both new policies and new attitudes - is no longer a luxury. In fact, it may be exactly what's needed to keep the American male, and America itself, competitive in the 21st century. 261

This is not to say that stereotypes pertaining to work and gender are univalent and inflexible. There are complicating factors, and stereotypical notions shift and reform according to context and the variable of class. They also shift according to presentation - a man with children is given

260. Williams, supra note 13.

261. Romano \& Dokoupil, supra note 147. 
benefits in the workplace where a single man is not-on the outdated assumption that the family wage is an appropriate earnings ideal. A man who tries to integrate substantive caring responsibilities into his working schedule, however, is not treated to either the respect or the benefit that the man who is a father, but not a caretaker, is. The most successful route for a man within this schema is to do little that troubles workplace structures. Women, on the other hand, are still caught in a double bind. Women are penalized for being mothers by having their ability called into question. Women are equally penalized for trying to be gender non-conformists when they eschew the caretaking role and adopt a more "masculine" approach to the workplace. Within these parameters, neither men nor women can easily or fully navigate the combination of caretaking and work, a fact that prevents individuals from flourishing in substantive, personal ways.

A positive benefit of the mancession/momcession debate is that it has energized conversation about gender stereotypes and has produced speculation about how to reimagine masculinity to meet the needs of both modern families and workplaces. One conclusion generated by the mancession is that men will either need to move out of the traditionally male employment fields or continue to suffer from unemployment, underemployment, or inflexible employment. As the Newsweek article very succinctly put it, "To survive in a hostile world, guys need to embrace girly jobs and dirty diapers. ... [I]t's time to reimagine masculinity at work and at home." 262 The good news is that recent surveys have also found a willingness on the part of fathers to prioritize childcare over work. In Careerbuilder's annual Father's Day survey, thirty-seven percent of the fathers surveyed said that they would "leave their job if their spouse or significant other's income could comfortably support the entire family" and forty-two percent would "take a pay cut of 10 percent or more" in order to spend more time with their children. ${ }^{263}$

It is time to reimagine what jobs are appropriate for which gender, what a day at the office looks like, how marriage partners share caretaking responsibilities, and who stays at home with a child. The mancession/momcession debate has generated the tools as well as the willingness for us to interrogate tenacious gender stereotypes about the trusted worker and the marginalized caretaker that still inform and organize workplaces.

262. Id.

263. Thirty-Seven Percent of Working Dads Would Assume Mr. Mom Role if Spouse Could Financially Support Family, CareerBuilder.com's Annual Father's Day Survey Finds, CAREERBUILDER.COM (June 9 , 2008) http://www.careerbuilder.com/share/aboutus/pressreleasesdetail. aspx?id=pr437\&sd=6\%2f9\%2f $2008 \&$ ed $=12 \% 2 \mathrm{f} 31 \% 2 \mathrm{f} 2008$. 
This debate has also created an opportunity for us to reimagine the norms that keep both men and women from being full and productive people within multiple spheres. What remains is for the workplace to synchronize its operations with these revised gender concepts and caretaking-friendly structural determinants. In recreating these norms and workplace values, there is deep possibility to match the needs and desires of a forwardlooking workforce with the long-term interests of employers. 


\section{STUDENT NOTES}


